\title{
Study of Density and Void Ratio Relation for Reconstituted Tropical Residual Soil at Varying Fines Contents
}

\author{
J. O. Okovido ${ }^{\mathrm{a}, *}$, E. O. Obroku ${ }^{\mathrm{b}}$ \\ ${ }^{a}$ Department of Civil Engineering, University Of Benin, Benin City, Edo State, NIGERIA. \\ ${ }^{b}$ Department of Civil Engineering, Igbinedion University Okada, Edo State, NIGERIA.
}

\begin{abstract}
Soil behaviour may be hinged on the relative composition and nature of arrangement of the various component fractions embedded in the soil. Whether the component proportions of the fines (silt/clay) are interwoven within the voids of coarse (sand) grains, or that the coarse grains are dispersed within the fines mass would determine sandy or clayey soils characteristics. Density and voids ratio assessments of tropical residual soils were conducted in this study on compacted reconstituted binary blends of fines and coarse soils which were also subjected to cycles of sustained compression loads. The soil was separated into fines and coarse fractions by sieving through a $75 \mu \mathrm{m}$ sieve. Reconstituted soil samples were prepared from these two fractions in varying percentages ranging from zero fines content (0:100) to 100 percent fines fraction (100:0) in 10 percent increment. The results indicate that the moisture contents and changes in density due to moisture movements were insignificant for fines less than 40 percent. Compacted density and voids ratios were optimally maximum and minimum with values of about $2000 \mathrm{~kg} / \mathrm{m}^{3}$ (dry density) and 0.2 respectively at fines contents of 20 percent. An optimal degree of saturation was also obtained at 20 percent fines. Optimum moisture contents were also obtained at about 30 percent with the corresponding optimum dry densities ranging from $2100 \mathrm{~kg} / \mathrm{m}^{3}$ to $2200 \mathrm{~kg} / \mathrm{m}^{3}$ from compression tests. The thresholds fines content therefore would depend on the stress state of the soil and may be about 20 or 30percent for subgrade assessments or geotechnical considerations respectively and beyond the threshold fines content the fines fraction makes up the stress-carrying matrix for the soil mass thus controlling the soil behaviour. .
\end{abstract}

Keywords: aggregates, voids ratio, saturation, fines

\section{INTRODUCTION}

The effects of fines on varied physical and engineering properties of soils have been of increasing concern to several researchers. Some of these investigated the effects of plastic fines [1-6]; while others worked on non-plastic fines ([7-13]. One notable characteristic highlighted is the threshold fines content at which various engineering properties of the soil change as observed by the various researchers. Some of the characteristics that have been related to fines content include liquefaction potential, soil response to cyclic loading, shear stress, compression behaviour and soil mechanical behaviour. These researches also show the underlying importance of knowing the threshold fines content of certain soils as these could assist engineers in taking measures to reinforce the soil against any potential catastrophic failure to existing or intending structures to be placed on it.

\footnotetext{
${ }^{*}$ Corresponding author (Tel: +234(0) 802328 4237)

Email addresses: johnokovido@rocketmail.com (J. O. Okovido), obroku.endurance@iuokada.edu.ng (E. O.
} Obroku)
Threshold fines content recorded for various soils were done based on varied soil parameters investigated by various researchers. The parameters investigated include critical state parameters, liquefaction potential and susceptibility, soil mechanical instability (shear stress) and consolidation behaviour. Generally, the fines content observed for all the soils investigated in these works can be categorized into two broad groups, namely cohesionless and cohesive fines. For cohesionless soils, the fines content are in the range of 15 to $40 \%$ although most of the threshold content were between 20 and $35 \%$. The cohesive fines were reported to be between 20 and $30 \%$.

When liquefaction potential of soils were investigated, the threshold reported for the soils were generally 20 and $30 \%$, although extremes between 15 and $35 \%$ were also observed in few cases $[3,6,11,13,14]$.

Threshold frequency observed by the researchers mentioned above reveals that sand containing fines have much greater resistance than clean sand with the same SPT N-Value. It also shows that the tendency becomes signifi- 
cant as fines content increases and that no soil containing more than $20 \%$ fines liquefied. The results also show that beyond the threshold fines content the fines fraction make up the stresscarrying matrix or skeleton for the soil mass thus controlling the soil behaviour. Of significance also is that below the threshold fines content, liquefaction potential of the soil decreases with increasing fines but the behaviour is reversed once the threshold fines content is exceeded.

On the effect of silt content on void ratio, the threshold content was in the range of 30 to $40 \%$ for both cohesionless soils investigated. The general trend is that at constant confining pressure, as the fines content increases, the void ratio decreases until the threshold fines content was reached. The reverse however became the case as the fines content increased beyond the threshold where further increase in the fines content resulted in increase in the void ratio [14]. When four mixtures of non-plastic fines and sand were experimented, Toyoura sand mixed with crushed silica fines, Toyoura sand mixed with glass beads, Fujian sand mixed with crushed silica, and Fujian sand mixed with glass beads. It was reported that all four mixtures show a trend that the maximum void ratio first decreases and then increases with increasing fines content. The fines content marking the transition appears to be around $40 \%$, which can be roughly regarded as the threshold fines content of the mixtures [8].

Soil mechanical behaviour and mechanical instability were also investigated to determine the threshold fines content at which the soil characteristics change from being coarse-grained skeleton governed to being fines grained governed. The threshold content for this behaviour is generally in the range of 20 to $35 \%$ both for plastic and nonplastic fines. The conclusion reached was that beyond the threshold, fines content becomes responsible for the true behaviour of the soil. The lower threshold values were usually those of plastic soils while the higher values were those obtained for cohesionless soils. Contractive phase behaviour was reported at fines contents below the threshold content while dilatancy phase behaviour was reported beyond the threshold fines content. For the case of coarse grained skeleton, the coarse grain contacts play a primary role, whereas with the increase of fines content, the fine grain contacts begin to play an increasingly important role as the coarse grains become dispersed in a system wherein they provide a secondary reinforcement effect. This was also reported for compression behaviour of cohesionless soils [1, 2, 5, 7, 9, 10].

Owing to the vital role threshold fines content play in the evaluation of various engineering characteristics of soils, the density and void ratio characteristics of reconstituted tropical residua red soil was investigated in this study with a view to determining the threshold fines content of the soil.

\section{MATERIALS AND METHODS}

Soil samples were obtained from sampling depths of 1.50 to 3.0 metres below natural ground level (mbgl), within the premises of the University of Benin. The choice of sampling depth is that majority of foundations installed in this soil are shallow foundations and the depths of footings are often within this range. These recovered soil samples were taken to the laboratory and identification tests performed on representative samples. The fines were obtained by sieving the soil through 75 micron sieve size with the residue of silt and clay taken as the fines. The soil retained on the 75 micron was soaked in a solution containing 4percent sodium hexametaphosphate compound for a minimum of 20 hours, and was thereafter sieved through a 75 micron sieve. Soil fraction retained on the sieve was isolated and termed the "coarse fraction". The fines and coarse fractions were reconstituted and experimentally examined with varying proportions of fines (clay/silt) to coarse fractions from nil to 100percent fines. Table 1 shows the manner in which the soil was reconstituted.

Various geotechnical tests were performed on the reconstituted samples which included moisture content determination, density measurement and Oedometer consolidation tests. The laboratory compaction was carried out using standard laboratory test method as described in standard code of soils testing. [15]. The soil was compacted by dropping a steel mass onto thin layers in a cylindrical mould using an amount of compaction energy per unit volume giving by:

$$
\text { Energy }=\frac{m \times h \times b \times n}{V}
$$

where $m=$ mass or weight of hammer, $h=$ height of drop, $b=$ number of blows per layer, $n=$ number of layers and $V=$ volume of mould.

The BS light compaction (Proctor method) which utilises a $2.5 \mathrm{~kg}$ rammer was used in the experiment. Soil preparation procedures included curing the reconstituted samples compacted at the optimum moisture content of the mix for a minimum of 20 hours. The soil was compacted in three layers of equal thickness into the compaction mould of $1000 \mathrm{~cm}^{3}$. Each layer received 25 blows from the rammer falling through a height of $300 \mathrm{~mm}$.

The Oedometer test was carried out as outlined in relevant sections of the standard [15]. Some aspects include the use of a rigid confining ring to prevent lateral strains and produce $\mathrm{K} 0$ stress conditions and to prevent lateral drainage thus ensuring one-dimensional drainage conditions. Porous discs were also placed at the top and bottom of each soil specimen to act as permeable boundaries. The specimen height was $20 \mathrm{~mm}$, extruded from the compaction mould with the same treatment as outlined for the compaction sample as stated above. Loading was applied through a load hanger and a counter-balanced lever system with a load ratio of about 10:1. Each pres- 
Table 1: Reconstituted soil fraction composition.

\begin{tabular}{|c|c|c|}
\hline Reconstituted soil mix ratio & $\begin{array}{c}\text { Percentage of coarse fraction } \\
(>75 \text { microns sieve })\end{array}$ & $\begin{array}{c}\text { Percentage of fine fraction } \\
(<75 \text { microns sieve })\end{array}$ \\
\hline $100 A+0 B$ & 100 & 0 \\
\hline $90 A+10 B$ & 90 & 10 \\
\hline $80 A+20 B$ & 80 & 20 \\
\hline $70 \mathrm{~A}+30 \mathrm{~B}$ & 70 & 30 \\
\hline $60 \mathrm{~A}+40 \mathrm{~B}$ & 60 & 40 \\
\hline $50 \mathrm{~A}+50 \mathrm{~B}$ & 50 & 50 \\
\hline $40 A+60 B$ & 40 & 60 \\
\hline $30 \mathrm{~A}+70 \mathrm{~B}$ & 30 & 70 \\
\hline $20 \mathrm{~A}+80 \mathrm{~B}$ & 20 & 80 \\
\hline $10 A+90 B$ & 10 & 90 \\
\hline $0 \mathrm{~A}+100 \mathrm{~B}$ & 0 & 100 \\
\hline
\end{tabular}

sure increment was administered to the soil for about 24 hours. A starting pressure of roughly $0.023 \mathrm{~N} / \mathrm{mm}^{2}$ was impacted to each soil sample. Other pressures impacted from the weights are respectively $\mathrm{N} / \mathrm{mm}^{2}, 0.091 \mathrm{~N} / \mathrm{mm}^{2}, 0.181 \mathrm{~N} / \mathrm{mm}^{2}$ and $0.362 \mathrm{~N} / \mathrm{mm}^{2}$.

The equations used in determining the void ratios of the reconstituted soils include:

$$
e_{f}=e_{i}-\frac{\triangle H}{H_{i}}\left(1+e_{i}\right)
$$

Where $e_{f}=$ equilibrium void ratio at the end of consolidation, and $e_{i}=$ the initial void ratio, $H_{i}$ $=$ the initial thickness for the pressure increment (mm) and $\triangle H=$ change in the thickness over the pressure increment (mm).

Parameters which were used to determine the threshold fines content of the soil include moisture, density and void ratio characteristics. These were chosen because of the contrasting behaviour of these parameters before and after the threshold fines content was attained. Some researchers have also evaluated the threshold fines content from similar parameters $[2,8,14]$.

\section{RESULTS AND DISCUSSION}

\subsection{Primary Soil Properties}

The primary soil was as obtained from the site before segregation into fines (silt/clay) and coarse (sand) fractions. The results of identification assessments and index tests are shown in Table 2.

The significant amount of fines in the primary soil, the high plasticity index implies that the soil has significant plastic characteristics and may likely pose compressibility challenges when subjected to intense loading from structures. The dominant clay mineral, Kaolinite would significantly influence the characteristics of the soil.

\subsection{Moisture-Density Characteristics of Re- constituted Tropical Residual Soil}

The optimum moisture content increases with higher levels of fines content from all coarse to 100 percent of fines. But the rise in the optimum moisture content up until 40percent fines is marginal, just 2.2 percent rise from 12.2 to 14.4
Table 2: Properties of the primary tropical residual soil.

\begin{tabular}{ll}
\hline Test parameter & Value \\
\hline Natural moisture content & 18.57 percent \\
Specific gravity & 2.54 \\
Percentage finer than 425microns & 73.13 percent \\
sieve & \\
Percentage finer than 75 microns & 43.0 Percent \\
sieve & \\
Silt content & 22.0 Percent \\
Clay content & 21.0 Percent \\
Combined silt/clay content & 43.0 Percent \\
Liquid limit & 54.04 Percent \\
Plastic limit & 32.84 Percent \\
Plasticity index & 21.20 Percent \\
Colour & Reddish brown \\
Activity [21] & 1.010 \\
Highway Research Board & A-7-5(5) \\
Classification &
\end{tabular}

percent. But the trend changes rapidly with increased grade beyond 40 percent fines such that it is more than doubled to 31.8 percent at 80 percent fines and was 37.2 percent at 100 percent fines. This is illustrated in Fig. 1.

Therefore changes in the soil's fines content between zero and 40 percent may not affect the moisture content of the soil and in this assessment it can be considered to remain approximately constant at 13.3 percent. The fines content of the primary soil was found to be 43 percent and the associated optimum moisture content of the reconstituted soil is about 16.4 percent. These conditions may be assumed to be sufficiently close in character to the reconstituted soils. The primary soil may be existing at optimum moisture conditions, and reconstituting at the optimum moisture at approximately the same fines content may reproduce samples with close enough characteristics with the primary soils. It can therefore be deduced that reconstituting soils are fairly representative when certain soil characteristics are desired such as the optimum moisture content.

There is increase in densities as soon as fines fractions are introduced into the sand sample. The increase continues until maxima(2300 and $2000 \mathrm{~kg} / \mathrm{m}^{3}$ ) are achieved at about 20 percent fines 


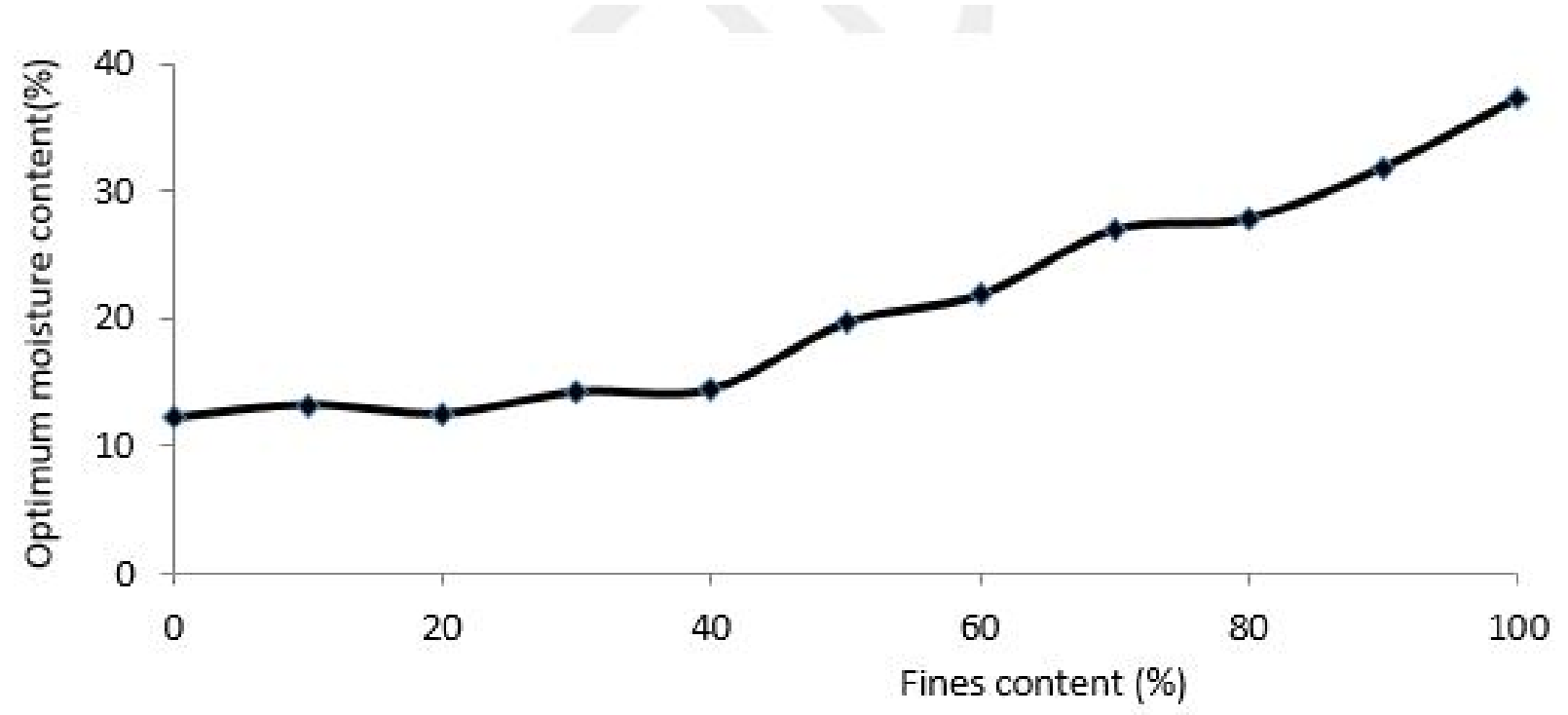

Figure 1: Optimum moisture content of of reconstituted soils.

for both the bulk and dry densities respectively. Thereafter, the densities reduce steadily until the fines contents reach 80percent. Between 80 and 100 percent fines in the reconstituted soil, the bulk density trend reverses and thereafter increases in the same order of preceding grade approach, but the dry density appeared to be constant within this terminal range. This trend is illustrated in Fig. 2.

The trend shows that at fines content less than 20 percent, the soil matrix characteristics is governed by coarse fractions hence increase in fines and water content resulted in the matrix being well packed until the maximum densities were recorded at 20 percent fines content.

The relative proportions of the dry density to the bulk density are illustrated in Fig. 3.

The trend shows that the ratio reduces marginally within 90 and 87 percent for fines content less than 40 percent where the ratio is 0.874 , but the absolute grade of reduction increases rapidly for soils with more than 40percent fines.

The proportion is 0.782 and 0.729 at 80 and 100 percent fines contents respectively. The reduction in density associated with complete loss in moisture can therefore be assumed to be constant at an average of 11.5 percent for fines contents less than 40percent, but can be as much as 22 and 28 percent at 80 and 100 percent fines contents.

It could be inferred that the corresponding loss of mass in surcharging operations could be significant even at an intermediate level of 15percent loss of density. The shift in pivotal behaviour at 40 percent fines contrasts with the optimal densities which occurred at 20percent fines content. This shows that beyond the threshold fines content the fines fraction makes up the stress-carrying matrix or skeleton for the soil mass thus controlling the soil behaviour.

The voids ratio characteristics with increasing fines content is illustrated in Fig. 4. The characteristics changes at optimum moisture content of
$20 \%$. Initial increase in fines content

from zero resulted in a reduction in void ratio from its initial value of over 0.4 to the minimum value of about 0.2 at 20 percent fines. Further increase in fines content resulted in steady increase in voids ratio until the maximum void ratio was observed at fines content of about 80 percent which remained fairly constant with further increase in fines content up to 100percent fines content. This characteristic also highlights 20 percent fines content as the threshold beyond which a change in the characteristics of the reconstituted soil with respect to voids ratio was observed [8].

The degree of saturation of the compacted reconstituted soils show that at maximum density conditions the soil may rapidly reach saturation at 10 percent fines content. Figure 5 highlights the degree of saturation characteristics with increasing fines content.

The degree of saturation of the reconstituted soils initially increased to the maximum at 20percent fines content and remained fairly constant thereafter until the fines content reaches about 70 percent where further drop in the saturation was observed. The saturation was also examined for the intermediate primary soil which was considered to be soil reconstituted at 40 percent fines content. The change in the saturation with increasing fines content is also shown in Fig. 5.

Assuming a constant voids ratio of the intermediate soil level of reconstitution but with the equivalent moisture conditions at the various stages of reconstitution, the degree of saturation was reexamined. The intermediate primary soil apparently became saturated at about 44 percent fines and 17percent moisture content. These observations are sufficiently close to the condition of the primary soil, and the implication could be that with the appropriate compacting effort saturation of the primary soil can be achieved at the natural moisture content. Beyond the intermediate soils condition, the degree of saturation increased pro- 


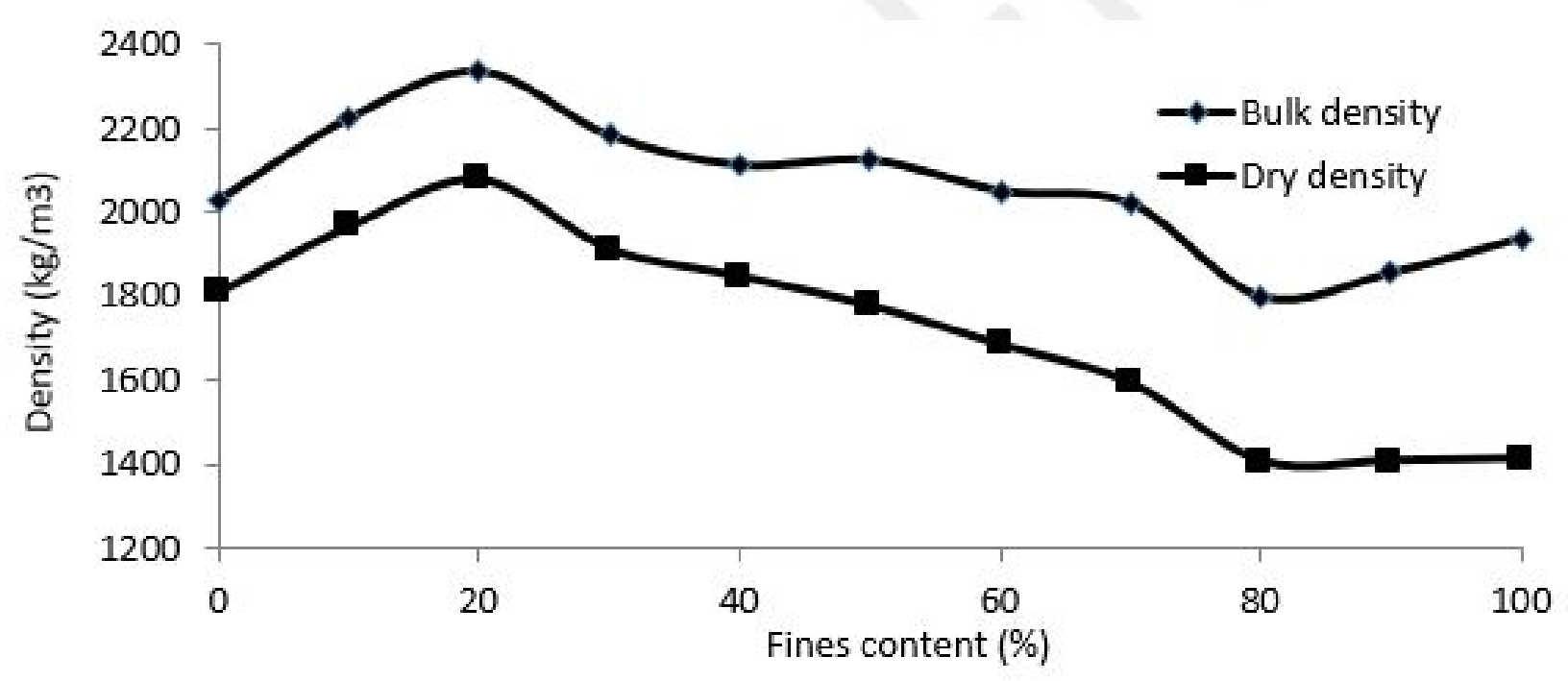

Figure 2: Densities of the reconstituted soils.

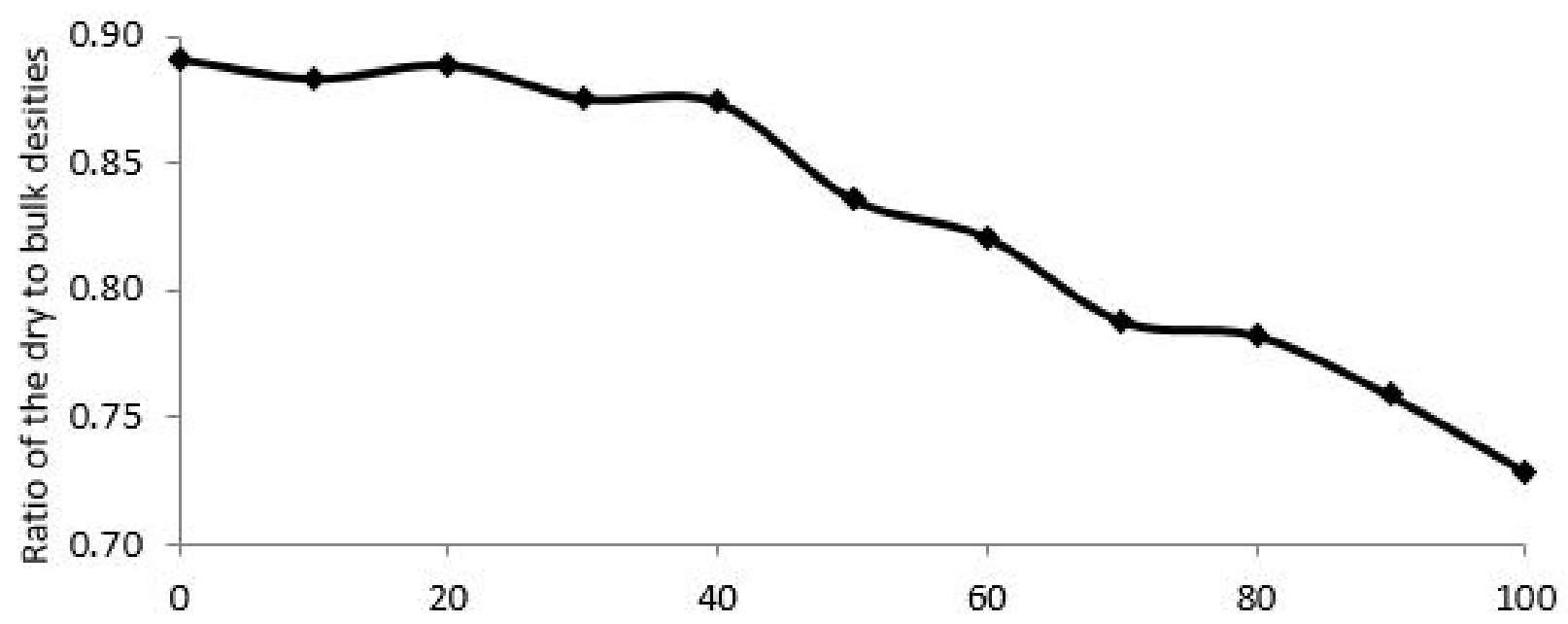

Figure 3: Proportion of changes between the bulk and dry densities of reconstituted soils.

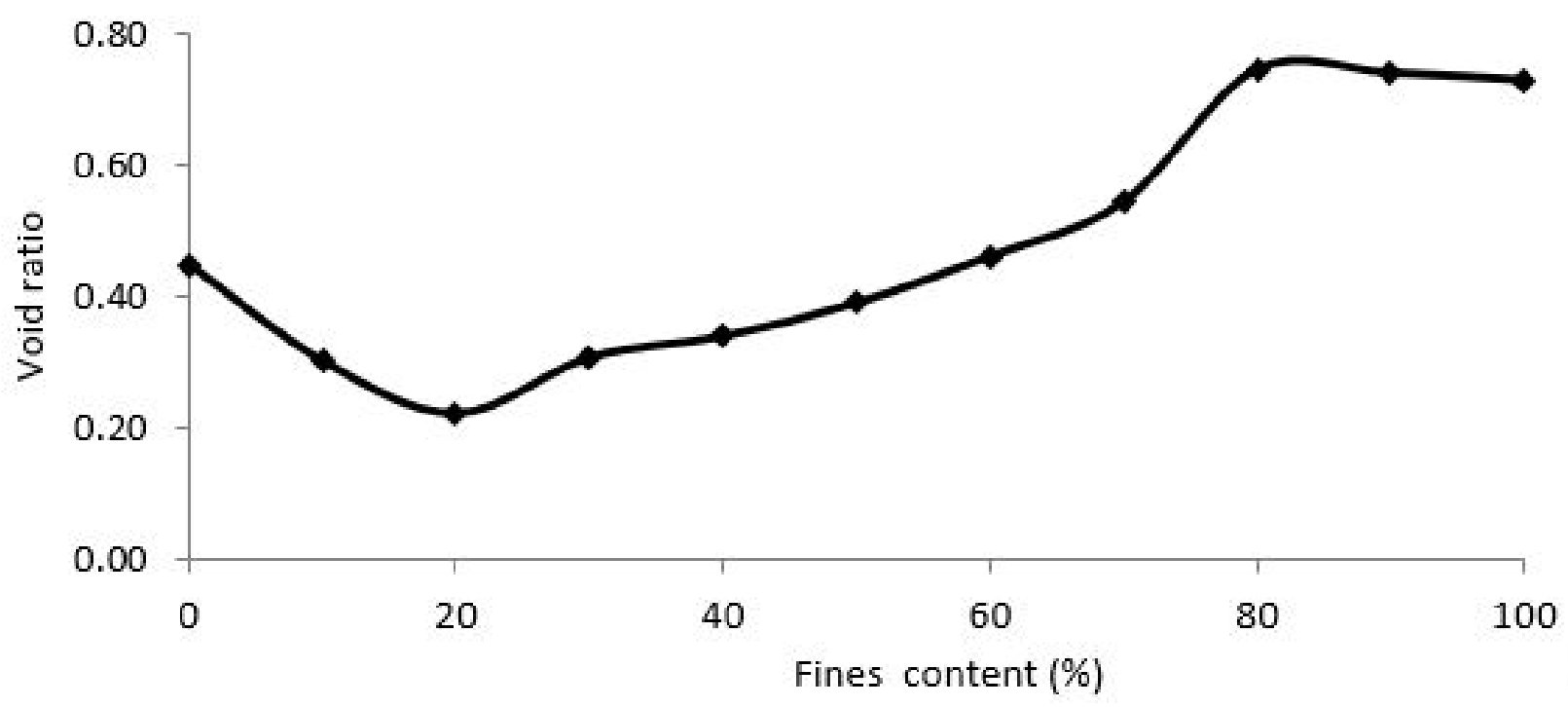

Figure 4: Voids ratio changes of reconstituted soils. 


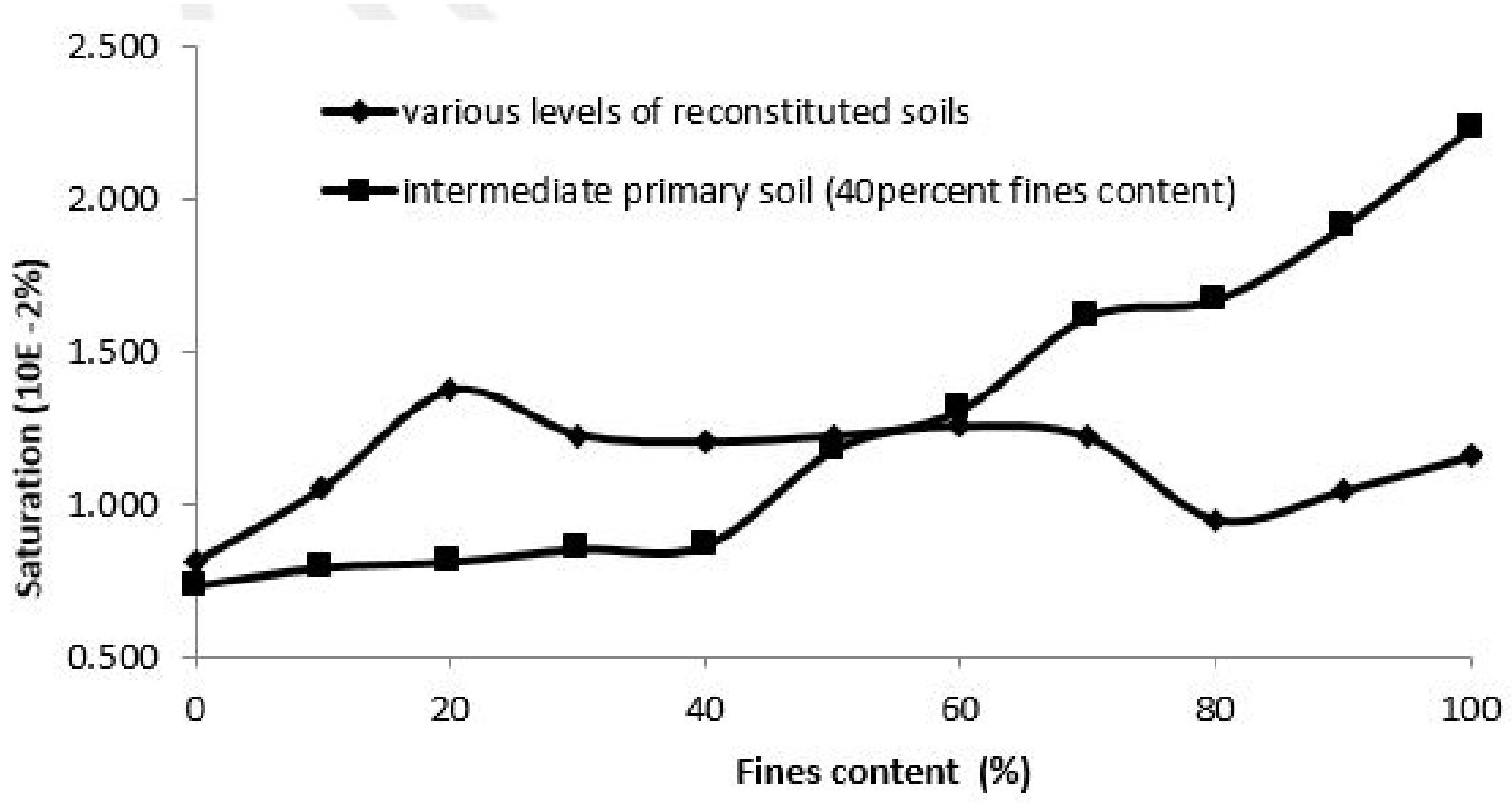

Figure 5: Degree of saturation of the reconstituted soils.

gressively until it became maximum at 100percent fines content.

The ease with which saturation and even oversaturation was achieved should be noted. Saturation implies that all the voids spaces are filled up with moisture. Oversaturation would suggest that the moisture may be holding the soil particles apart, or that the soil particles are floating. It's however not clear where the excess moisture of oversaturation is located, it may be suggested that the moisture could have been absorbed by the clay minerals thereby removing moisture from the pore spaces or soil matrix, otherwise pore pressures would inadvertently develop.

Most tropical red soils are classified as unsaturated soils and unsaturated soils' principles are recommended for their assessments. With the observed characteristics of these reconstituted soils, there is strong evidence that not all tropical red soils exists in unsaturated state but their degree of saturation may be a function of their fines content.

\subsection{Reconstituted Soil Properties under Oe- dometer Uniaxial Compression Condi- tions}

The voids ratios and densities characteristics of the reconstituted soils with increasing fines contents are shown in Fig. 6 and 7 respectively. There is reduction in density and consequent increase in void ratio resulting from relief as the soil is extracted from the compaction mould. These changes affect soils with fines content less than 70 percent and confining pressures of $0.180 \mathrm{~N} / \mathrm{mm}^{2}$. The reduction in densities is generally less than 5 percent but for 10 and 20 percent fines the reductions are within 10 and 15 percent.

The bulk densities increased for higher confining pressures with consequent reduction in voids ratios. But with increasing fines content the density increased until 30 percent fines and thereafter the bulk density reduces steadily until for every loading cycle initially increased until a fines content level of 80percent beyond which the densities are constant for cell pressures less than $0.045 \mathrm{~N} / \mathrm{mm}^{2}$, but for higher cell pressures it is another phase of density increase until the maximum fines content of 100 percent.

The observed voids ratio behaviours are in reversal of the density trends, the voids ratios reduced for increasing densities. There were reductions in voids ratios until the minimum voids ratio occurred at 30 percent fines and thereafter increased for each load cycle until 80percent fines content, after which samples subjected to cell pressures of $0.045 \mathrm{~N} / \mathrm{mm}^{2}$ and below exhibited no further significant change in voids ratios, but for higher confining pressures there were reduction in voids ratio. This puts the threshold fines content at 30 percent because after attaining this content, the behaviour of the soil became govern by the fines content hence the contrasting characteristics.

The saturation of the samples is nevertheless expected to increase with reducing voids spaces and reduce with higher voids content. For the various load cycles the saturations increased until maxima were achieved at 30percent fines, which is also the reconstituted soil condition for the maximum density and minimum voids ratios. This again pegs the threshold fines content at about 30 percent [2]. Figure 8 illustrates the trends in degree of saturation with increasing fines content. For samples confined with cell pressures as high as $0.045 \mathrm{~N} / \mathrm{mm}^{2}$ the saturation increases until fines content of about 25 percent when the soil becomes saturated, the saturation increases 


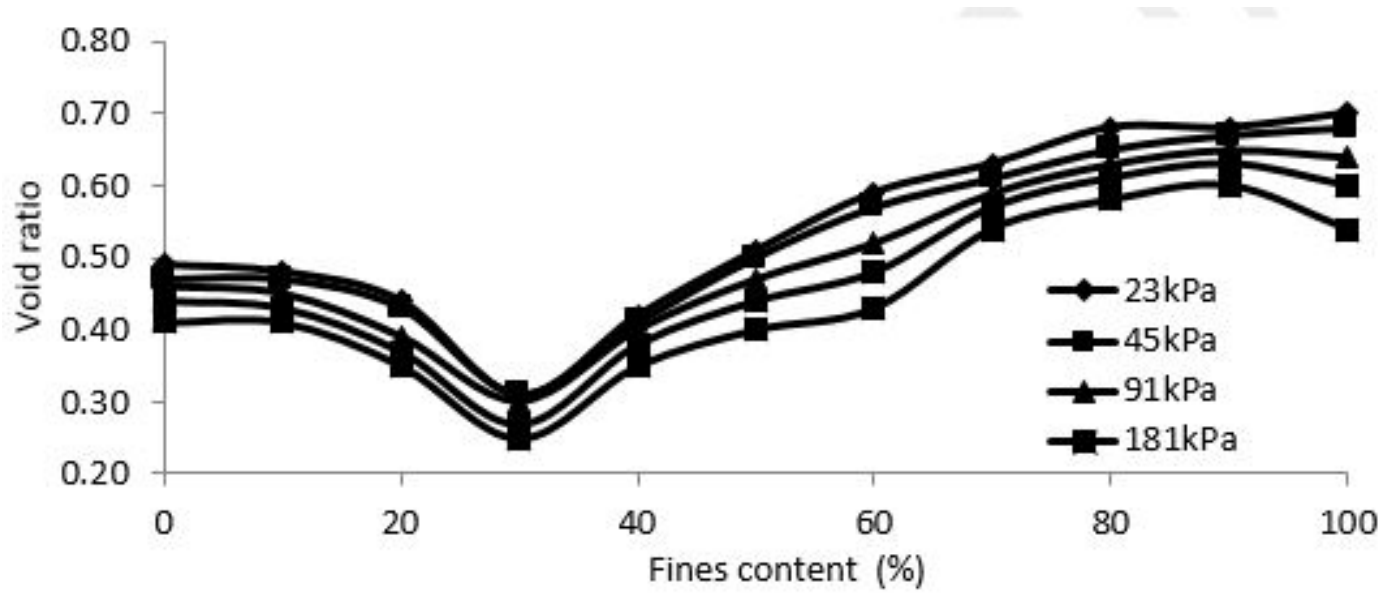

Figure 6: Soils voids ratio with changes in fines content.

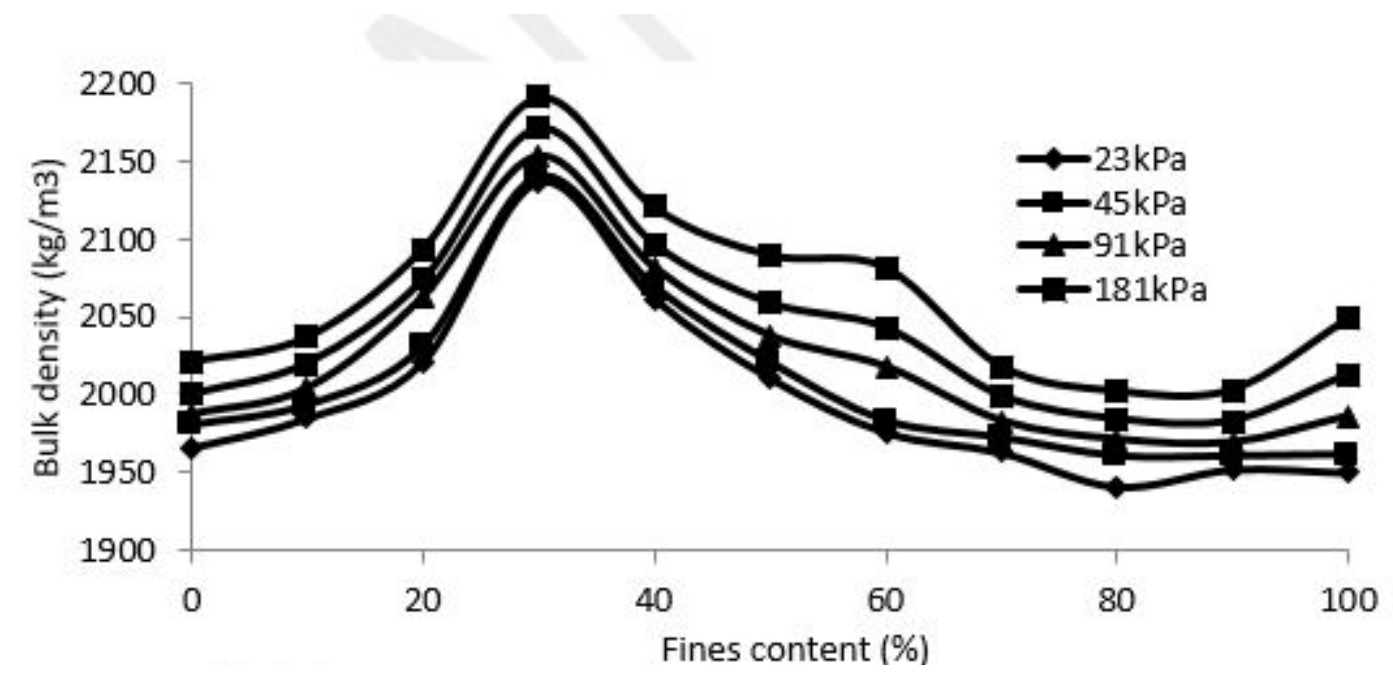

Figure 7: Soil bulk densities at various levels of fines content.

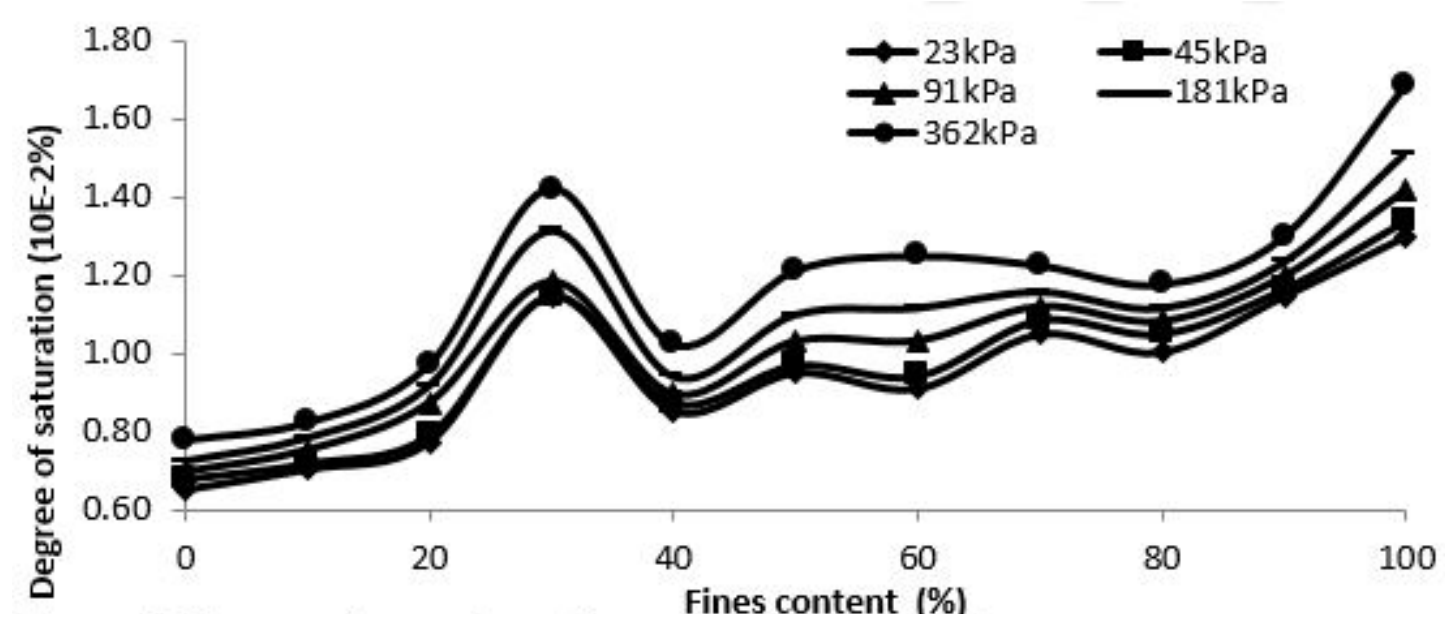

Figure 8: Degree of saturation of reconstituted soils under sustained oedometer uniaxial cell pressures. 
to maximum of just under 115 percent and thereafter reduced and at 35 percent fines the soil becomes unsaturated again and becomes about 90 percent at 40 percent fines. Saturation increased steadily again from this constitution and at 65percent the soils become saturated, and at 100 percent fines the degree of saturation was 133.5 percent. At the conditioning cell pressure of $0.023 \mathrm{~N} / \mathrm{mm}^{2}$ the saturations are a little less but follows the same trend pattern as the reconstituted soils confined at $0.045 \mathrm{~N} / \mathrm{mm}^{2}$. For higher confining pressures the voids contents are lower and higher saturations were achieved for each reconstitution.

With increasing fines and under higher confining pressures, saturations were achieved at fines contents within 20 and 25 percent. This rose to maxima of between 117 and 140 percent for confining pressures range of $0.091-0.362 \mathrm{~N} / \mathrm{mm}^{2}$ for reconstituted soils with fines content of 30 percent. The saturation thereafter reduced for increasing fines content until fines content of 40 percent when the trend reverses and the saturation increased again. For the highest confining pressure of $0.362 \mathrm{~N} / \mathrm{mm}^{2}$, the reconstituted soils remained saturated from 20 to 100 percent fines content. But for confining pressures of 0.091 and $182 \mathrm{~N} / \mathrm{mm}^{2}$, there were intermediate phases of unsaturation at $37-47$ and $39-43$ percent fines.

\section{CONCLUSION}

The influence of varying fines content on the density and void ratio characteristics of reconstituted tropical red soil was investigated and the findings are:

1. Increase in fines content initially led to an increase in the density of the reconstituted soil until the maximum density value is reached at about 20 percent fines content before further increase in fines content resulted in continuous decrease in the density of the reconstituted soils.

2. For fines contents less than 40 percent the optimum moisture remained approximately unaffected at a constant value but increased linearly for higher moisture contents.

3. The optimal minimum voids ratio was associated with the maximum density at 20percent fines. The degree of saturation initially increased with additions of fines and saturation at optimum moisture content was achieved at just less than 10percent fines. But when examined by oedometer one dimensional compression assessments, the maximum densities, minimum voids ratio and maximum degrees of saturation all occurred at 30percent fines, but saturations were achieved at within 20 and 25percent fines respectively associated with the highest and lowest confining cell pressures.
4. Optimum fines content would therefore depend on the state of stress of the soil, when compacted irrespective of the state of stress would be in the range of 20 to 30 percent although effects of moisture movements are not expected to have significant effects for fines contents less than 40 percent. A change in the behaviour of reconstituted lateritic soil with respect to void ratio, optimum moisture content, degree of saturation, was observed at an optimum(threshold) fines content.

This shows that beyond the threshold fines content the fines fraction makes up the stress-carrying matrix for the soil mass thus controlling the soil behaviour

\section{References}

[1] A. Mato, C. Tan, A. Makhtar, F. Pakir, and S. Chong, "Effect of fines content on critical state parameters of sand matrix soils," in AIP Conference Proceedings 1755, 2016, 060001.

[2] L. K., "Effect of fines mineralogy on the oedometric compressional behaviour of sandy soils," Journal of Civil Engineering and Construction Technology, vol. 4, no. 7, pp. 232-238, 2013.

[3] M. Benoula, H. Missoum, and K. Bendani, "Critical undrained shear strength of sand-silt mixtures under monotonic loading," Earth Sciences Research Journal, vol. 18, no. 2, pp. 149-156, 2013.

[4] A. Marto, C. Tan, A. Makhtar, N. Yunus, and A. Amaludin, "Undrained shear strength of sand with plastic fines mixtures," Malaysian Journal of Civil Engineering, vol. 25, no. 2, pp. 190-200, 2013.

[5] M. Ouyang and A. Takahashi, "Influence of initial fines content on fabric of soils subjected to internal erosion," Canadian Geotechnical Journal, vol. 2, pp. 1-62, 2014.

[6] A. Arab and M. Belkhatir, "Fines content and cyclic preloading effect on liquefaction potential of silty sand: A laboratory study," Acta Polytechnique Hungarica, vol. 9, no. 4, pp. 47-64, 2012.

[7] S. Yang, R. Sandven, and L. Grande, "Instability of sand - silt mixtures," Soil Dynamics and Earthquake Engineering, vol. 26, no. 2, pp. 183-190, 2006.

[8] J. Yang, , and L. Wei, "Collapse of loose sand with the addition of fines: The role of particle shape," Geotechnique, vol. 62 , no. 12 , pp. 1111-1125, 2012.

[9] Z. Yin, J. Zhao, and P. Hicher, "A micromechanics-based model for sand-silt mixtures," International Journal of Solids and Structures, vol. 51, no. 1, pp. 1350-1363, 2014.

[10] M. Bousmaha, H. Missoum, K. Bendani, M. Derkaui, and F. Belhouari, "Experimental study on mechanical instability of sand-silt mixtures," International Journal of Applied Engineering Research, vol. 11, no. 3, pp. 2149-2156, 2016.

[11] K. Tokimatsu and Y. Yoshimi. (2017, February) Criteria of soil liquefaction with spt and fines content. [Online]. Available: www.iitk.ac.in/nicee/wcee/article/ 8_Vol3_255.pdf

[12] M. Karim and M. Alam, "Equivalent granular void ratio concept for sand-silt mixtures," in Conference on Advances in Bridge Engineering-III, Dhaka, Bangladesh, 2015.

[13] R. Armstrong and E. Malvick, "Comparing of liquefaction susceptibility criteria," in 34th Annual USSD conference on Dams and Extreme Events - Reducing Risk of aging infrastructure under extreme loading conditions, San Francisco, California, 2014.

[14] M. Baziar, H. Shahnazari, and H. Sharafi, "A laboratory study on the pore pressure generation model for firouzhooh silty sand using hollow torsional test," International Journal Of Civil Engineering, vol. 9, no. 2, pp. 128-134, 2011.

[15] "Bs 1377-1-4:1990: British standard methods of test for soils for civil engineering purposes," British Standards Institution, 1990, london. 